\title{
Relation of Riverbank Erosion With Agricultural Landuse Practices on Floodplain of River Jaldhaka (Mansai) at Tikiner Char, Bhowerthana Village, Coochbehar, Westbengal, India
}

\author{
Tapas Barman \\ Researcher, M.A. in G.U., B.Ed in M.D.U \\ barmantapasg@gmail.com
}

\begin{abstract}
:
Background: The study examined the effects of agricultural landuse practices on riverbank erosion of floodplain of river Jaldhaka (Mansai) at Tikiner char (island), Bhowerthana village, Coochbehar, West Bengal. Riverbank erosion or bankline migration is a common phenomenon of mighty river Jaldhaka due to its braided condition, faulty land practices, agricultural landuse practices and other hydrological factors owns special attention in geosciences arena.

Results: Rivers are dynamic and thus through the process of erosion, transportation and deposition produces all dynamic landform along its course. While erosion is a natural process, human activities have increased by 10-40 times the rate at which erosion occurring globally.

Conclusion: The study was carried out using primary based on observation and interview method and it shows that the bankline migration due to erosion and agricultural practices of the study area. Resent bank erosion rate 8.71 meters/ year during 2010-15 has shown sign of gradual decline from its earliest records 17.92 meters/year during 1995-2010 at the eastern part of Tikiner char and aggradations at the rate 4.21 meters/ year during 2010-15 and 12.35 meters/ year during 1995-2010 in the western part of Tikiner char.
\end{abstract}

Keywords: Jaldhaka River, Riverbank erosion, Agricultural landuse practices, Floodplain, bankline migration.

\section{BACKGROUND}

Process of bank erosion are important in the development and evolution different channel forms, while the migration of river channel across their floodplains involves a combination bank erosion and deposition. Riverbank erosion is a geo-morphological phenomenon that found a wide room for scholarly discussion in last few years (Nanson and Hickin, 1986; Dunne et al., 1998; Tangri, 2000; Das et al., 2007; Pati et al., 2008). The riverbank erosion study of Pati et al. (2008) was done on Majuli, the largest river island of the world, which is situated in middle of the Brahmaputra River in Assam. Moreover, in recent years, the efficacious roles of bank erosion upon human living hood and societal issues have become another research interest especially within the Indian context (e.g. Bandyopadhyay et al., 2006; Thakur et al., 2012).

Generally, if a river channel is in equilibrium state, then at undisturbed conditions lateral channel changes normally take place through bank erosion and bar deposition which leads to high sediment exchange rates between the river channel and the floodplains. These processes consequently control lateral channel shifts, downstream sediment supply and availability, and floodplain configurations. A certain rise in bank erosion rate either because of increasing activity of the forces operating on the river banks or a decrease in the bank resistance which is not balanced by sufficient sediment deposition can offer an increase in channel width enforcing disequilibrium in the river system.

The bank erosion is very common process of change for all meandering rivers throughout the world. Being a natural riverine element, river banks can move away (erosion) or can advance (deposition) which can result in meandering migration, channel avulsion and change in channel width (Bartley et al., 2008). Being a geomorphic-fluvial process, bank erosion is actually culminated through a series of processes which can be viewed through a set of three groups (Charlton, 2008). The first one covers the pre-weakening processes which prepare the set for bank erosion $e$.g. alternate cycles of wetting 
and drying; the second one assembles the direct fluvial entrainment processes and the third one includes the processes of bank failure.

Regarding the primary agents of bank erosion, Wolman (1959) picked peak river discharge, rise in water stages, existing moisture conditions and precipitation, temperature and especially frost occurrences.

In addition with these natural controlling factors, the role of human interventions in the form of landuse alteration, agricultural expansion, flow regulation and channelization, alteration of bank materials have also been documented of exerting some moderating influences upon bank erosion. Human activity has modified the transfer, storage and yield of sediment in many drainage basins worldwide. Suspended sediment from agriculture is the single largest source of pollution. It leads to discoloration and can damage the infrastructure of water supply network.

The sediment discharge 2-3 times increases due to agricultural landuse practices on river floodplain (Wolman, 1967). Empirical studies have shown that vegetated channels erode more slowly, and are deeper and narrower than similar non-vegetated banks. According to Beats and Henry, 1928 sediment discharge increase due to agricultural practices from $15 \%$ to $29 \%$.

The amount of soil lost annually from agricultural land in the United States is estimated by the use of the Revised Universal Soil Loss Equation (RUSLE) (Renard et al., 1994; Brady and Weil, 1996, pp. 569-578).

$$
\begin{aligned}
& \mathrm{A}=\mathrm{RKLSCP} \\
& \text { Where, } \mathrm{A}=\text { predicted soil loss (soil annual loss in tons/acre) } \\
& \mathrm{R}=\text { climatic erosivity (rainfall and runoff) } \\
& \mathrm{K}=\text { soil erodibility } \\
& \mathrm{L}=\text { slope length } \\
& \mathrm{S}=\text { slope gradient or steepness } \\
& \mathrm{C}=\text { cover and management } \\
& \mathrm{P}=\text { erosion-control practices }
\end{aligned}
$$

Contextually, the present paper has gone through the aiming towards the understanding of the processes of bank erosion and channel width alterations over time with relation to agricultural landuse practices. Comprehensively, focus has been devoted to (a) the mean bank erosion rates, processes of bank erosion and bankline movements for the concerned reach, (b) channel width variations over space-time and their connections with bank erosion and areal changes (erosion-deposition), and (c) present agricultural landuse practices across the Jaldhaka (Mansai) river floodplain at Tikiner char, Bhowerthana.

\section{SigNifiCANCE OF THE STUDY}

The bank erosion is a very common process of change for all rivers form throughout the world. Bank erosion is developed due to two main causes- natural and human activities. In human activities agricultural landuse practices on river bank is an important and critical parameter. Due to agricultural practices on river bank erosion increases 10-40 times at which erosion occurring globally. A study relating to bank erosion and agricultural practices on floodplain of Jaldhaka (Mansai) River at Tikiner char thus bears immense significance.

\section{OBJECTIVES OF THE STUDY}

The objectives of the study are: To study the physical setting of the study area.

$>$ To examine the bank erosion characteristics of the study area.

$>$ To study the patterns of agricultural landuse practices on the study area.

$>$ To examine the relation of bank erosion and agricultural landuse practices on the study area.

$>$ To identify the mitigation of bank erosion problems of the study area. 


\section{Materials ANd Methods}

Riverbank erosion is a recurrent and highly unpredictable phenomenon. It is merely recognizable that riverbank erosion is taking place due to climate change. However, study reveals that it does not occur due to climate change rather it happens through accelerating the rate of erosion through uneven distribution of precipitation, increased surface run-off and changing agricultural landuse practices.

\subsection{Description of the study area}

The study area was carried out on floodplain of river Jaldhaka (Mansai) at Tikiner char, Bhowerthana village of Sitlkuchi in Coochbehar district and $3 \mathrm{~km}$ from market of Bhowerthana village. The latitude and longitude of the study area is $20^{\circ} 12^{\prime} 27.06^{\prime \prime} \mathrm{N}$ to $26^{\circ} 12^{\prime} 47.06^{\prime \prime} \mathrm{N}$ and $89^{\circ} 17^{\prime} 24.34^{\prime \prime} \mathrm{E}$ to $89^{\circ} 17^{\prime} 31.87^{\prime \prime}$ E respectively. Elevation of the region is $48 \mathrm{~m}$ above sea level. Lithologically it is the recent developed floodplain region composed of very course sand, sand, silts and clay. Along $3 \mathrm{~km}$ with river Jaldhaka (Mansai) the study area falls.

The annual average temperature and total rainfall of the study area range between $19^{\circ} \mathrm{c}$ and $31^{\circ} \mathrm{c}$ and $3000 \mathrm{~mm}$ and $3945 \mathrm{~mm}$ respectively.

Landuse pattern of the region changed significantly since the last $21^{\text {st }}$ century specially 2000 's because of the immense in-migration of population. In 1995 to 2010 around $20 \%$ to $30 \%$ natural vegetation area have been converted into croplands and human settlements. In present landuse pattern of the study area, the total estimated land area is about $3.30 \mathrm{sq} \mathrm{km}$ ( 330 hectors), where, $1.75 \mathrm{sq} \mathrm{km}$ is covered by agricultural land, $0.80 \mathrm{sq} \mathrm{km}$ is covered by natural vegetation, $0.50 \mathrm{sq} \mathrm{km}$ is covered by sand and fallow land and rest $0.25 \mathrm{sq} \mathrm{km}$ is other elements.

Agricultural landuse practices of the study area are different from different seasons. In summer season the agricultural land are mainly practices for paddy (almost 75\%) cultivation. In winter season the multiple crops system are used for cultivation of agricultural lands. The agricultural landuse pattern in winter season is from the total agricultural land jute $8.6 \%$, tobacco $29.13 \%$, Chili $16.08 \%$, potato $5.21 \%$, tomato $1.3 \%$, others $21.73 \%$ and fallow land $17.82 \%$.

Almost $30 \%$ geographical land areas are eroded by the river Jaldhaka (Mansai) in the form of bank erosion.

\subsection{Method of data collection}

For the present study to collect the data used primary based of observation. The primary based of observation fulfill by interview and questionary method from the resident people. There were no any satellite imagery and toposheet maps for this remote area due to restriction of government.

\subsection{Sampling technique}
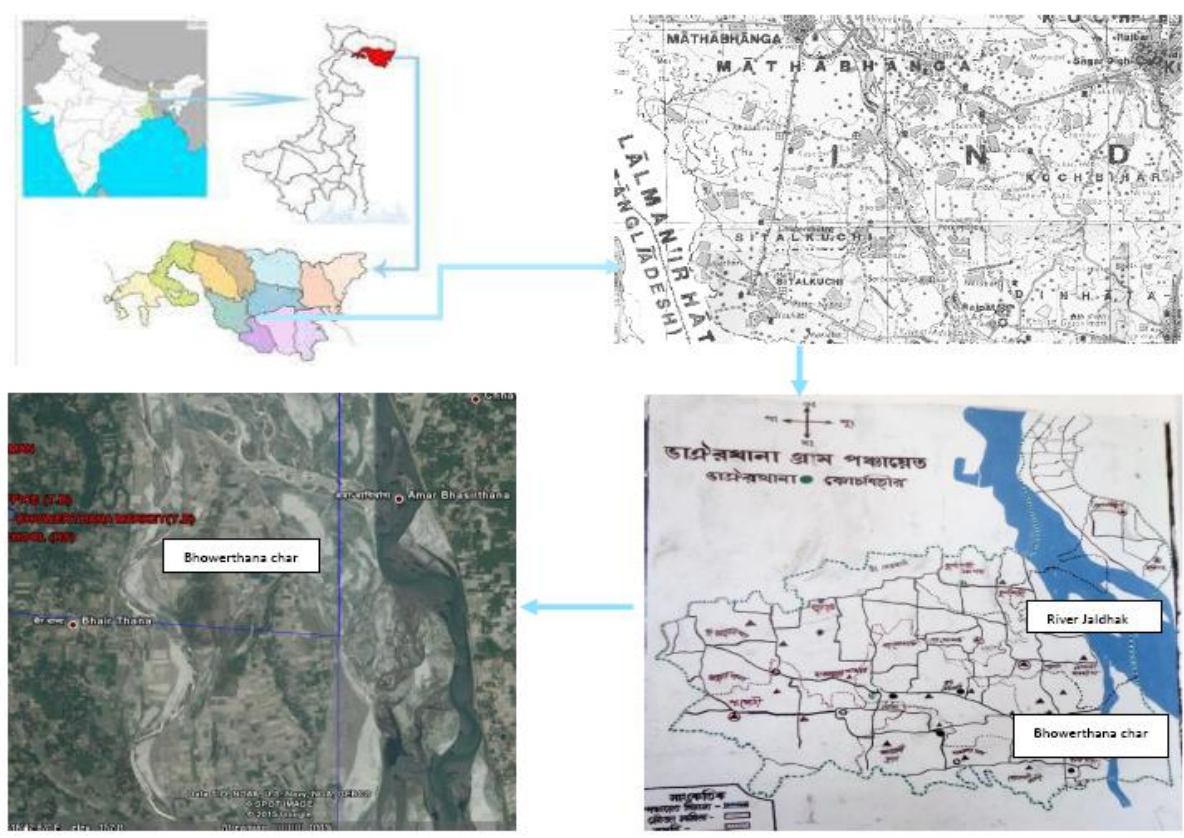

MAPS ARE NOT TO SCALE

Fig1. Location Map of the Study Area 
Sampling technique is used to analyze the socio-economic data. The sampling technique employed in this study has simple random sampling technique. After having list of households, sample size was determined proportionally to its number of households. Hence, a total 27 houses are selected by using simple random sampling from total of 54 household.

\subsection{Methods of Data Analysis}

In order to address the specified objectives, the study analyzed, summarized, and presented the data both qualitatively and quantitatively. The qualitative method was employed to analyze the opinions of farmers and substantiate the quantitative data obtained through questionnaires survey.

\section{RESUlTS AND DisCUSSION}

Field measurements- observation have been incorporated to find out the nature and trends of bank erosion and relation with agricultural landuse practices for the involved time span. Besides highlighting their trends, their possible causative explanations have also been provided in this section.

\subsection{Bankline movements and Bank erosion}

The analysis of bankline movements have suggested that's bank eroded gradually but at different rates and different directions at different time span. The dynamicity of the bankline has been studied in two phases linked with in (1995-2010 and 2010-2015). During the earliest phase of 1995-2010, a high degradational activities/ bank erosion found in the eastern part of Tikiner char. At the same phase at western part of Tikiner char a negative activity found (deposition of sediments). A gradually declining rate of bank erosion and deposition of sediment are found in eastern part and western part of Tikiner char respectively.

Resent bank erosion rate 8.71 meters/ year during 2010-15 has shown sign of gradual decline from its earliest records 17.92 meters/ year during 1995-2010 at the eastern part of Tikiner char (island) and aggradations at the rate 4.21 meters/ year during 2010-15 and 12.35 meters/ year during 1995-2010 in the western part of Tikiner char (the depositional sand bar is locally known as "char").

\section{Controlling Variables}

\subsection{Bank composition and Time}

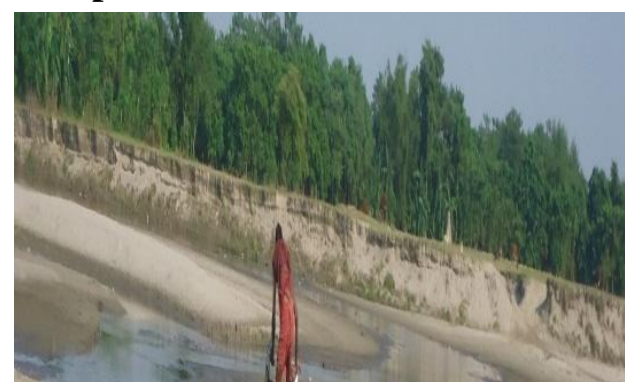

(A)

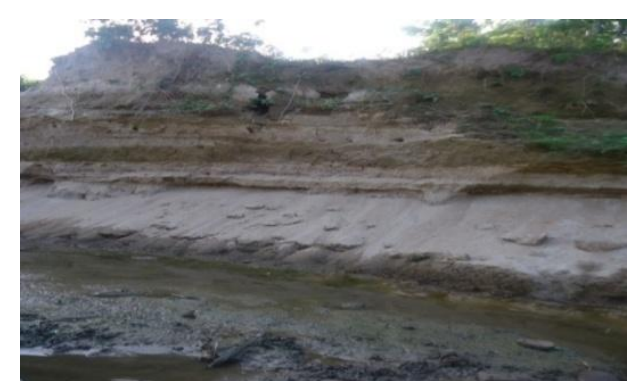

(B)

Plate6 (A) \& (B). River bank composition at the western part of the floodplain (char).

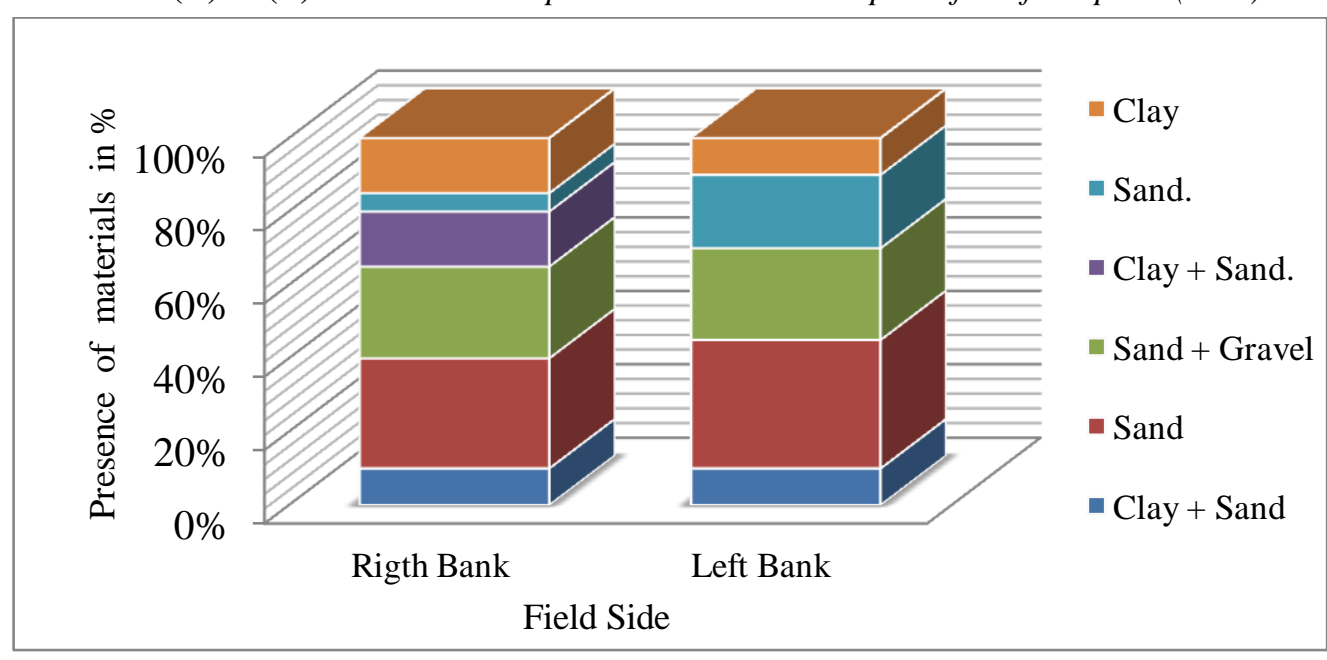

Chart1. Showing the composition of river bank (both) of Mansai (Jaldhaka) at Tikiner Char. 
Relation of Riverbank Erosion With Agricultural Landuse Practices on Floodplain of River Jaldhaka (Mansai) at Tikiner Char, Bhowerthana Village, Coochbehar, Westbengal, India

Bank composition perhaps is the most important concern in the present study. In fact, reach scale differences in bank erosion rate suggested serious bank stratigraphic significance. In relation to bank composition time is also a dominant factor of controlling bank erosion rate. In observation, the rate of bank erosion is 2 times more in eastern part then the western part of the study area.

\subsection{Riparian vegetation}

In acts as a protective cover for the river banks which by their roof reinforcements binds the bank soils and increase the soil cohesiveness. Perception surveys revealed that most parts of the floodplain (char) covered by some hardwoods (e.g., Khayer, Shisuk, nim etc) trees and different kinds of grasses which had enhanced the tensile strength of the bank walls and surfaces and thus had protected the banks from erosion earlier even during peak monsoons. With time, agricultural expansion towards the river is aggressively replacing the bank vegetation to different kinds of crops and vegetables. In 1995 to 2010 around $20 \%$ to $30 \%$ natural vegetation area have been converted into croplands and human settlements.

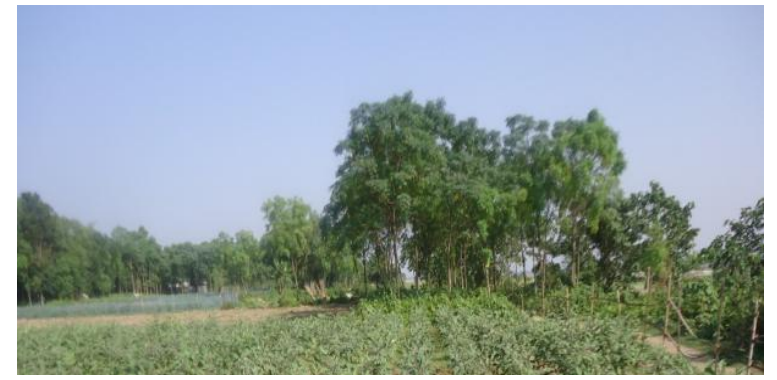

(A)

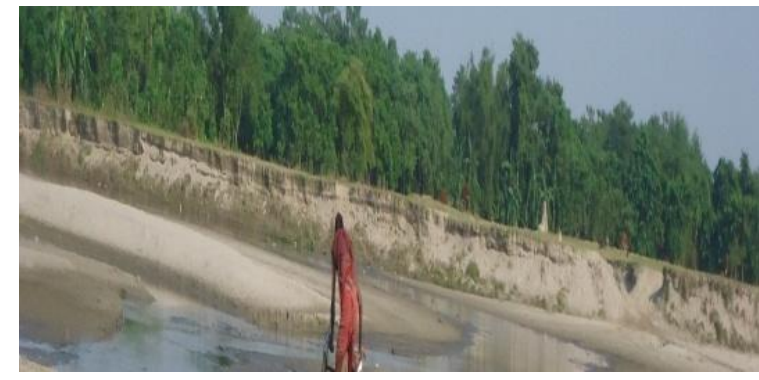

(B)

Plate 5(A) \& (B). Riparian vegetation

\subsection{Agricultural landuse practices}

In addition with increasing population, the agricultural landuse practices change with time. Clearing of riparian vegetation cover for agricultural use and changing of agricultural practices, soils of river bank become weak and eroded easily. In field observation, erosion process is two times more in the upper part of the study area than the lower part.

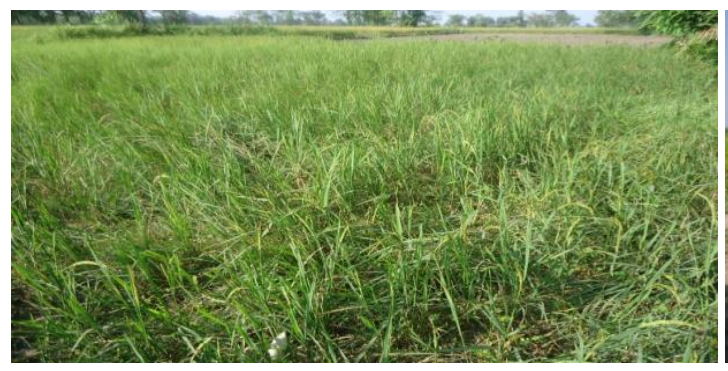

Plate1. Paddy practices on floodplain (char)

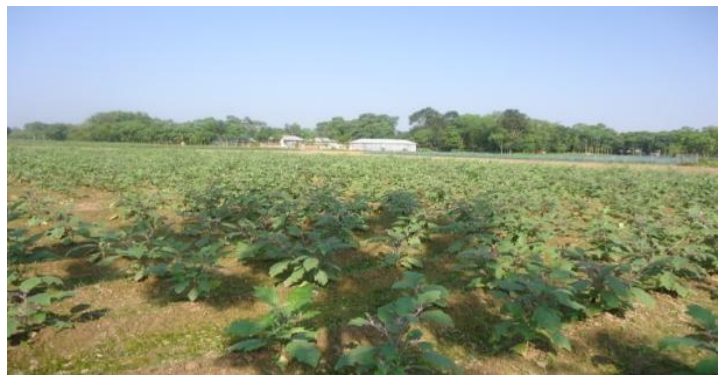

Plate3. Brinjal cultivation on floodplain

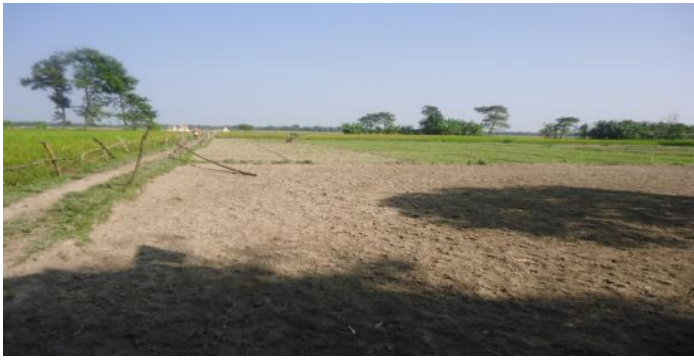

Plate2. Chilli cultivation on floodplain (char)

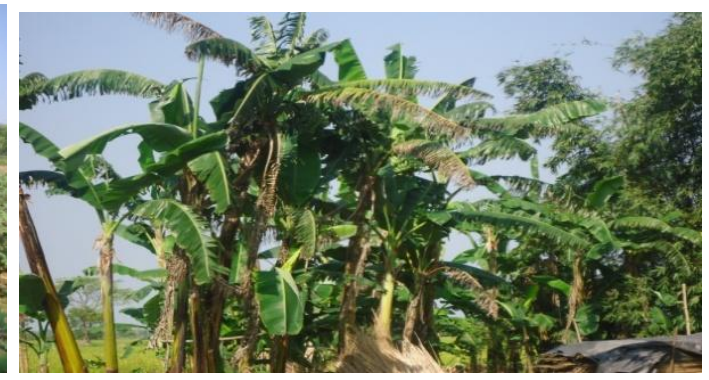

Plate4. Banana trees at Tikiner char (char)

\section{Conclusion}

Riverbank erosion and aggradations (sedimentation) over river bank due to changing of agricultural landuse practices a critical study. In the present study soil erosion as well as riverbank erosion and aggradations activity due to agricultural landuse practice is remarkable but gradually decreases at a 
small rate. Bank erosion of the study area is different in both sides in different time span. Resent bank erosion rate 8.71 meters/ year during 2010-15 has shown sign of gradual decline from its earliest records 17.92 meters/ year during 1995-2010 at the eastern part of the study area and aggradations at the rate 4.21 meters/ year during 2010-15 and 12.35 meters/ year during 1995-2010 in the western part of the study area.

Various erosion protection measures such as earthen embankments, spurs etc. are used to protect the area locally. Localized bank protection cannot provide a long-term solution to the problem of execution and subsequent maintenance of protection works as it become very difficult for the erosion and bed stratification of the river. A comprehensive scientific study of the bank materials as well as morphology of the river is needed to protect the area using eco-friendly materials and techniques such as Geotextile bags (or Geobags) for construction of embankments to protect river banks from severe scouring and erosion. They are also good for vegetative growth and provide habitat for species that are living around water and vegetation.

\section{ACKNOWLEDGEMENTS}

The authors are grateful to Dulal Barman for his helping hands during field surveys. We humbly thank the local residents of the study area for their guidance and important information during field studies and surveys.

\section{REFERENCES}

[1] Bandyopadhyay, K., Ghosh, S. and Dutta N. (2006) Eroded lives. Retrieved from http://www.mcrg.ac.in/eroded_lives.pdf

[2] Basu p. (2014), 'Prakriyasankranta Bhumirupbidya O Sangslistha Jalabiggan (Bengali version), $2^{\text {nd }}$ ed. Kolkata, pp- 232-237.

[3] Basu S. R. and Maiti R. (2010), 'Adhunik Bhumirup Biggan, Bhu-gathan O Bibartan' (Bengali version), $3^{\text {rd }}$ ed. Kolkata, p-249.

[4] Bloom A.L. (2009), 'Geomorphology- A Systematic Analysis of Late Cenozoic Landforms' $3^{\text {rd }}$ ed. New Delhi, pp-200-203,

[5] Chakraborty S. and Mukhopadhyay S. (2014), 'an assessment on the nature of channel migration of river Diana of the sub-Himalayan West Bengal using field and GIS techniques'. Arabian Journal of Geosciences, Online first article. doi: 10.1007/s12517-014-1594-5

[6] Chakraborty S.and Mukhopadhyay S., "Riverbank Erosion and Channel Width Adjustments across a Meandering Channel of North Bengal, India" Earth Science India, eISSN: $0974-8350$ Vol. 8 (III), July, 2015, pp. 61 - 78 http://www.earthscienceindia.info/61

[7] Das, A.K., Sah, R.K. and Hazarika, N. (2012) Bankline change and the facets of riverine hazards in the floodplain of Subansiri-Ranganadi Doab, Brahmaputra Valley, India. Natural Hazards, v. 64, pp. 1015-1028. doi: 10.1007/s11069-012-0283-5

[8] Gogoi C., Goswami D. C., "A study on bank erosion and bank line migration pattern of the Subansiri River in Assam using remote sensing and gis-technology" The International Journal Of Engineering And Science (IJES), Volume 2, Issue 9, Pages 01-06, 2013, ISSN (e): 2319 - 1813 ISSN (p): $2319-1805$

[9] Nanson G.C. and Hickin E.J. (1986), 'A statistical analysis of bank erosion and channel migration in western Canada'. Geological Society of America Bulletin, v. 97, pp. 497-504

[10] Opaminola D. N., Imoke E. D., Agnes O. M., "Effects of agricultural land use practices on the soils in cross river basin, Ogoja - Nigeria" Universe of Emerging Technologies and Science ISSN: 2349 - 655X Volume I Issue V - October 2014, http://www.uniets.com

[11] Prokop P. and Sarkar S. (2012), 'Natural and human impact on landuse change of the SikkimeseBhutanese Himalayan piedmont, India'. Quaestiones Geographicae, v. 31(3), pp. 61-75. doi: 10.2478/v10117-012-0010-Z

[12] Rudra K. (n.d.), 'the encroaching Ganga and social conflicts: The case of West Bengal, India'. Retrieved from http://www.gangapedia.iitk.ac.in/sites/default/files/Rudra.pdf

[13] Tegegne Tatek Belay, 'Perception of Farmers on Soil Erosion and Conservation Practices in Dejen District, Ethiopia'. International Journal of Environmental Protection and Policy, Vol. 2, No. 6, 2014, pp. 224-229. doi:10.11648/j.ijepp.20140206.15 
Relation of Riverbank Erosion With Agricultural Landuse Practices on Floodplain of River Jaldhaka (Mansai) at Tikiner Char, Bhowerthana Village, Coochbehar, Westbengal, India

[14] Thakur, P.K., Laha, C. and Aggarwal, S.P. (2012), 'River bank erosion hazard study of river Ganga, upstream of Farakka barrage using remote sensing and GIS. Natural Hazards', v. 61, pp. 967-987. Doi: 10.1007/s11069-011-9944-Z

[15] Wolman, M.G. (1959) Factors influencing erosion of a cohesive river bank. American Journal of Science, v. 257, pp. 204-216.

\section{AUTHOR'S BIOGRAPHY}

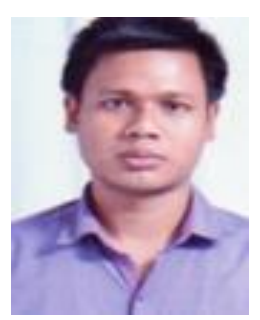

Tapas Barman, A Research Scholar Of Geography, Mastered In Geography At Gauhati University, B.Ed At Maharshi Dayanand University. His Research Interest Field Are Fluvial Geomorphology And Environmental Studies. 